

\section{Sumário}

ATIVISMO JUDICIAL E CONTROLE DE POLÍtICAS PÚBLICAS........................................................14 Rodrigo Monteiro da Silva

JuRisdição Voluntária No CPC/2015 COMO MEIO DE RESOluÇão DE 'CONTROVÉRSIAS' COM A AdministraÇão PÚBliCA ....................................................................................................29

Jefferson Carús Guedes

A MEDiaÇão COMUNitÁRIA COMO FERRAMENTA DE ACESSO A JUSTIÇA E DESENVOLVIMENTO NO

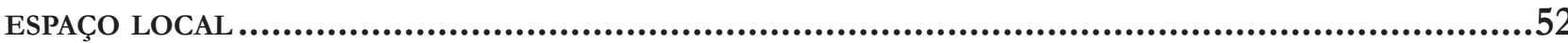

Daniela Arguilar Camargo

LEGITIMIDADE CONSTITUCIONAL DA ATUAÇÃO INTERNACIONAL DOS MUNICÍPIOS BRASILEIROS: UMA Leitura À lUZ DA TEORia DA Constituição Dirigente .65

Regina Claudia Laisner e Danilo Garnica Simini

JUdiCIALIZAÇão DE POLÍTICAS PÚbliCAS EM PROL DOS ANIMAIS: UMA VISÃo DE SAÚDE ÚNICA ....84 Luiz Gustavo Gonçalves Ribeiro e Clarice Gomes Marotta

JudicializAÇão DA SAÚDE, ATIVISMO JUDICIAL E O CONSEQUENTE DESEQUILÍBRIO DO ORÇAMENTO PÚBLICO

Juvêncio Borges Silva e João Paulo Jucatelli

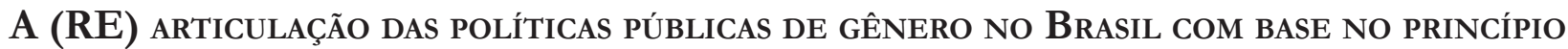
JURÍDICO DA SUBSIDIARIEDADE E DA DESCENTRALIZAÇÃO 117

Tamiris Alessandra Gervasoni e Marli Marlene Moraes da Costa

Desenvolvimento sustentável, educação e democracia: o caso

"Escola Sem Partido" 134

Veyzon Campos Muniz

Políticas de aCesso aberto para trabalhos CiENTíficos: INTERESSE PÚblico E DiReitos De AUTOR

Eduardo Altomare Ariente 
Financiamento CUltural no Brasil CONTEMPORÂNEO 172

Frederico Augusto Barbosa da Silva

Naturaleza y Constitución 193

Livio Perra

REGULAÇÃO AMBIENTAL DA ATIVIDADE MINERÁRIA: UMA ANÁLISE ECONÔMICA DE COMPLIANCE 208

Lorena Machado Rogedo Bastianetto e Magno Federici Gomes

O NEODESENVOLVIMENTISMO E A QUESTÃo AMBIENTAL: O PAPEL DA HIDROELETRICIDADE NO SISTEMA ENERGÉTICO BRASILEIRO.

Andreza Aparecida Franco Câmara

O COMPARTILHAMENTO DE DADOS E INFORMAÇÕES PESSOAIS DE CONSUMIDORES: O ABUSO DOS FORNECEDORES E AS PROPOSTAS APRESENTADAS NO PLS 181/2014 .................................247 Héctor Valverde Santana e Rafael Souza Viana

UTILIZAÇÃO DA COMPUTAÇÃO EM NUVEM NO PODER LEGISLATIVO: PERCEPÇÕES DOS GESTORES E

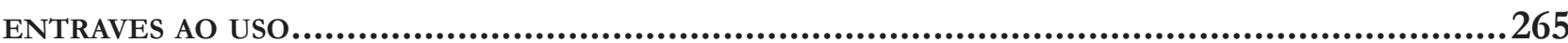
Igor Vinicius de Lucena Diniz, Lucas dos Santos Costa e Marcos Fernando M. Medeiros

O PROCESSO PENAL E A ENGENHARIA DE CONTROLE DA POLÍtTICA CRIMINAL Antonio Henrique Graciano Suxberger e José Wilson Ferreira Lima

Gestão de Presídios por Parcerias Público-Privadas: uma análise das atividades passíVEIS DE DELEGAÇÃO 305

Fernando Borges Mânica e Rafaella Brustolin 


\title{
Ativismo judicial e controle de políticas públicas*
}

\section{Judicial activism and public policy control}

\author{
Rodrigo Monteiro da Silva**
}

\begin{abstract}
Resumo
O presente artigo tem a intenção de examinar, teoricamente, sem maiores aprofundamentos em casos concretos, o dinamismo do chamado "ativismo judicial", de modo que ao magistrado seja possível interpretar as normas constitucionais, com foco a ampliar seu sentido ou alcance, com a finalidade de possibilitar a intervenção do Poder Judiciário, visando conferir efetividade ao direito fundamental à boa gestão pública.
\end{abstract}

Palavras chave: Ativismo judicial. Políticas públicas. Direito fundamental.

\section{Abstract}

This paper intends to examine the dynamics of so-called "judicial activism", so that the magistrate is possible to interpret the constitutional provisions, in order to expand its meaning or scope, in order to allow the intervention of the Judiciary, in order to give effectiveness to the fundamental right to good governance. The aim is toalso highlight the role that public prosecutors have as a driver institution the effective materialization of various public policies.

Keywords: Judicial activism. Public policies. Fundamental right.

* Recebido em 13/09/2016 Aprovado em 06/02/2017

** Mestrando em Direito e Garantias Fundamentais pela Faculdade de Direito de Vitória FDV; Membro do Grupo de Pesquisa "Estado, Democracia Constitucional e Direito Fundamentais"; Especialista em Direito Público pela Universidade Gama Filho (RJ); Promotor de Justiça (MP-ES). Email: rodrigomonteiro.es@ gmail.com

\section{INTRODUÇÃo}

A possibilidade de controle das mais diversas políticas públicas pelo Poder Judiciário é tema recorrente em nossa doutrina.

Em razão do crescente déficit de dignidade ${ }^{1}$ verificado na sociedade contemporânea, é preciso reconhecer o papel proeminente, assumido paulatinamente pelo Poder Judiciário como destinatário comum das decepções sociais levadas cada vez mais aos tribunais, principalmente quando está em pauta a discussão sobre os direitos fundamentais em seu núcleo essencial.

O Estado democrático de direito reclama uma sociedade justa, permeada por instituições firmes e eficientes, de modo a atender aos anseios básicos de seu povo.

1 Usa-se o termo "déficit de dignidade" para referir-se à ausência do Estado na materialização das mais diversas prestações públicas aptas a garantir a todo cidadão uma vida digna. 
Quando nos deparamos com situações em que o núcleo essencial dos direitos fundamentais encontra-se em risco, cabe ao Poder Judiciário intervir para buscar a materialização daquilo que, convencionalmente, passou a ser denominado "mínimo existencial".

Não há a intenção de se pregar a existência de um governo de juízes, mas, sim, delinear com clareza as formas e momentos em que o Poder Judiciário, com a ativa participação do Ministério Público, deve agir para compelir, democraticamente, o Poder Executivo a respeitar a vontade política do Constituinte Originário.

No mesmo sentido, importante destacar que a atuação ativa dos magistrados em nada viola a regra constitucional estampada junto ao artigo $2^{\circ}$, da Carta Cidadã, inerente ao princípio da separação dos poderes.

Ressalte-se que o presente trabalho aponta algumas considerações acerca da possibilidade de o Poder Judiciário retificar a conduta administrativa sempre que presente alguma transgressão a direito prestacional de caráter fundamental.

\section{DisCRICIONARIEDADE ADMINISTRATIVA E O CONTROLE JUDICIAL DE POLÍtICAS PÚBLICAS}

Segundo conceito trazido por Celso Antônio Bandeira de $\mathrm{Mello}^{2}$, discricionariedade é a margem de liberdade que remanesça ao administrador para eleger, segundo critérios consistentes de razoabilidade, um, dentre pelo menos dois comportamentos cabíveis, perante cada caso concreto, a fim de cumprir o dever de adotar a solução mais adequada à satisfação da finalidade legal, quando, por força da fluidez das expressões da lei ou da liberdade conferida no mandamento, dela não se possa extrair, objetivamente, uma solução unívoca para a situação vertente.

A discricionariedade denota o dever do administrador público de se buscar a melhor solução para um problema posto.

É preciso, mais uma vez, lançar mão dos ensinamentos de Celso Antônio Bandeira de $\mathrm{Mello}^{3}$ que assevera:

[...] a discrição é a mais completa prova de que a lei sempre impõe o comportamento ótimo. [...] quando a lei regula discricionariamente uma dada situação, ela o faz deste modo exatamente porque não aceita do administrador outra conduta que não seja aquela capaz de satisfazer excelentemente a finalidade legal.

Claudio Tenório Figueiredo de Aguiar ${ }^{4}$ com acerto defende que, apesar da legitimidade democrática dos Poderes Executivo e Legislativo, que são, originariamente, vocacionados para a definição das políticas públicas, por conta do déficit de dignidade popular verificado em países periféricos como o nosso, é preciso reconhecer o papel proeminente, assumido, paulatinamente, pelo Poder Judiciário como destinatário comum das decepções sociais levadas cada vez mais aos tribunais, principalmente quando está em pauta a discussão sobre os direitos fundamentais em seu núcleo essencial.

Há que se reconhecer, portanto, uma constante judicialização da política, fenômeno decorrente do papel central que a dignidade da pessoa humana e os direitos fundamentais passaram a ocupar no ordenamento jurídico pátrio.

Nesse sentido, importante lembrar que, em razão do caráter normativo da Constituição, formada por normas jurídicas abstratas de forte tendência política e que se abrem às interpretações cariadas, acaba por

2 MELLO, Celso Antônio Bandeira de. Discricionariedade e Controle Judicial. 2. ed. São Paulo: Malheiros, 2010. p. 48.

3 MELLO, Celso Antônio Bandeira de. Op.cit., p. 32.

4 AGUIAR, Claudio Tenório Figueiredo. Ministério Público e políticas públicas. Coordenadora: Patrícia Villela. Rio de Janeiro: Lumen Juris, 2009. p. 03. 
viabilizar entendimentos diversos sobre assuntos complexos, exigindo a intervenção pacificadora do Poder Judiciário.

A atuação do Poder Judiciário nesse contexto estará vinculada à omissão quanto à oferta daquilo vinculado ao núcleo essencial dos direitos fundamentais, não sendo viável a referência à Separação dos Poderes como fator impeditivo de enfrentamento do mérito da causa por meio da adoção de uma visão procedimentalista da Constituição. Tampouco se poderá admitir a justificativa da falta de legitimidade democrática do referido Poder na medida em que atua exatamente como contraponto em defesa das minorias ${ }^{5}$.

Descabida a ideia de que o juiz, ao assumir a posição do agente eleito, violaria o princípio democrático e pondo em risco o equilíbrio da tripartição dos poderes.

De se destacar as reiteradas motivações trazidas pelo Poder Executivo no sentido de justificar determinadas omissões relevantes no tocante à implementação de políticas públicas, apontando a limitação orçamentária e a existência de recursos finitos como causa para a inércia.

Não se nega que a escassez de recursos, sempre incapazes de dar conta de todas as necessidades da população, seja uma realidade presente, conduzindo o Estado às escolhas trágicas sob o manto da reserva do possível, porém, no que toca à essência dos direitos fundamentais, essa justificativa não seduz, sendo certo que uma parte significativa desses recursos públicos se esvai pelo caminho da corrupção, sonegação fiscal e, sobretudo, má gestão administrativa, o que exige mecanismos eficazes do controle do sangramento ${ }^{6}$ dessas verbas por aqueles que resolveram assumir posição de destaque na política nacional.

Não só por esse motivo, José Marinho Paulo Junior ${ }^{7}$ salienta que as políticas públicas são sindicáveis pelo Poder Judiciário. Havendo transgressão frontal ao direito prestacional, cabe, sim, ao Poder Judiciário a função de retificar a conduta administrativa, se revestida de ilegalidade ou inconstitucionalidade, mesmo quando escorada em "discricionariedade".

O mesmo autor ${ }^{8}$ salienta que ninguém deseja um governo de juízes, mas sim definir, claramente, os espaços constitucionais em que o Poder Judiciário deve agir para compelir democraticamente o Executivo a respeitar a vontade política do Constituinte Originário.

\section{Ativismo Judicial}

O assunto ativismo judicial é seguramente um daqueles que tem proporcionado debates no direito brasileiro. Enquanto muitos acastelam que o magistrado seja ativo, outros rechaçam essa possibilidade.

Ao analisar o contexto em que o debate é inserido, mostra-se perceptível que o fenômeno do ativismo judicial está, fundamentalmente, conectado à crescente judicialização dos conflitos e a ampliação da participação dos juízes na realização de políticas públicas. Mas, então, o que expressa o termo ativismo judicial e qual a sua origem?

Para Luís Roberto Barroso9 ${ }^{9}$ o ativismo judicial é um estilo, uma escolha do Juiz na maneira de interpretar as normas constitucionais, de modo a ampliar seu sentido ou alcance, em regra está diretamente ligado a uma contração do Poder Legislativo; o autor escreve que o ativismo judicial está associado à ideia de uma

5 Idem, p. 09.

6 AGUIAR, Claudio Tenório Figueiredo. Ministério Público e políticas públicas. Coordenadora: Patrícia Villela. Rio de Janeiro: Lumen Juris, 2009. p. 10.

7 PAULO JUNIOR, José Marinho. Ministério Público e políticas públicas. Coordenadora: Patrícia Villela. Rio de Janeiro: Lumen Juris, 2009. p. 140.

8 Idem, p. 141.

9 BARROSO, Luís Roberto. Ativismo Judicial e Legitimidade Democrática. Disponível em: < http://www.oab.org.br/oabeditora/users/ revista/1235066670174218181901.pdf>. Acesso em: 06 jun. 2014. 
participação maior do Poder Judiciário na materialização de direitos, mas, principalmente, na aplicação direta da Constituição Federal em casos não expressamente contemplados em seu texto, sem que para tanto haja a manifestação do Poder Legislativo. Além disso, a postura ativista, também, está ligada à obrigação do Poder Pública de praticar ou se abster de praticar determinadas condutas.

Luiz Flávio Gomes ${ }^{10}$ assevera que há ativismo judicial quando o juiz se considera no dever de interpretar a Constituição para garantir direitos fundamentais.

Ultrapassado o aspecto conceitual é necessário registrar que o ativismo judicial não é peculiar ao Poder Judiciário do Brasil. O Judiciário ou Cortes de outros países vêm atuando ou já atuaram em situações de implementação de políticas públicas.

No Brasil o fenômeno ativismo judicial deriva de um novo padrão constitucional adotado pela Carta Magna de 1988, que abraçou uma nova ordem constitucional, em que foi instituído um Estado Democrático de Direito, baseado nos direitos e garantias fundamentais em substituição a um Estado autoritário, em que os direitos e garantias fundamentais se subordinavam ao Estado.

Não é desnecessário afirmar que um dos principais órgãos do Poder Judiciário "ativista" é o Supremo Tribunal Federal, que dispõe de ferramentas constitucionalmente previstas para tomada de suas decisões.

$\mathrm{O}$ assunto é polêmico tanto na doutrina quanto na jurisprudência, entretanto, antes de trazer tal celeuma, é deveras fazer uma distinção entre ativismo judicial e judicialização. Para Luiz Flávio Gomes ${ }^{11}$, quando há interpretação da constituição para garantir um direito, há judicialização, o ativismo ocorre quando o magistrado inova o ordenamento jurídico pátrio.

A judicialização é um fato que deriva do modelo constitucional que se adotou. Se, de uma norma, é possível deduzir uma pretensão, deve o magistrado conhecer da matéria, decidindo-a. O ativismo judicial é uma atitude, é uma forma escolhida pelo Juiz de interpretar as normas constitucionais que acontecem quando há uma não atuação do Poder Legislativo, ou seja, quando há um impedimento em que as demandas sociais não são atendidas de modo efetivo.

O ativismo judicial está associado à ideia de uma participação intensa do magistrado para concretizar direitos e garantias fundamentais.

Lenio Streck ${ }^{12}$, ao tratar do assunto, afirma que:

Judicialização é contingencial. Num país como o Brasil, é até mesmo inexorável que aconteça essa judicialização (e até em demasia). Mas não se pode confundir aquilo que é próprio de um sistema como o nosso (Constituição analítica, falta de políticas públicas e amplo acesso à Justiça) com o que se chama de ativismo. O que é ativismo? É quando os juízes substituem os juízos do legislador e da Constituição por seus juízos próprios, subjetivos, ou, mais que subjetivos, subjetivistas (solipsistas). No Brasil esse ativismo está baseado em um catálogo interminável de "princípios", em que cada ativista (intérprete em geral) inventa um princípio novo. Na verdade, parte considerável de nossa judicialização perde-se no emaranhado de ativismos.

É preciso destacar que o ativismo do Poder Judiciário decorre, principalmente, de uma delegação por parte dos Poderes Legislativo e Judiciário, seja porque tais Poderes se mostram ineficazes no desenvolvimento de políticas públicas, seja porque a questão é polêmica e não querem os políticos resolver o problema e ficar com uma imagem negativa frente aos eleitores.

Tanto o ativismo judicial quanto a judicialização constituem fato inelutável. O Poder Judiciário, quando

10 GOMES, Luiz Flávio. O STF está assumindo um ativismo judicial sem precedentes? Jus Navigandi, Teresina, ano 13, n. 2164,4 jun. 2009. Disponível em: <http://http://jus.com.br/revista/texto/12921. Acesso em: 06 jun. 2014.

11 GOMES, Luiz Flávio. O STF está assumindo um ativismo judicial sem precedentes? Jus Navigandi, Teresina, ano 13, n. 2164, 4 jun. 2009. Disponível em: <http://http://jus.com.br/revista/texto/12921. Acesso em: 06 jun. 2014.

12 STRECK, Lenio Luiz. Hermenêutica jurídica em crise: uma exploração hermenêutica da construção do direito. 10. ed. Porto Alegre: Livraria do Advogado, 2011. p. 15. 
provocado, não possui alternativa a não ser se pronunciar sobre a questão. Entretanto, a maneira como exercer tal competência é o que determinará ou não a existência do ativismo judicial. A judicialização, sempre, vai existir, uma vez que ao Poder Judiciário não é dada a faculdade de se omitir quando provocado; já o ativismo judicial é uma faculdade, uma atitude do magistrado.

João Maurício Adeodato ${ }^{13}$, ao escrever sobre o assunto, esclarece que:

No Brasil o problema a que a autora se refere aparece muito mais claramente, sobretudo diante de um poder legislativo inoperante e de uma legislação inadequada sobre os processos de escolha política. Daí que juízes singulares, e não apenas tribunais superiores, criam literalmente comandos gerais, que só o purismo da técnica dogmática impede de chamar de "leis", dado seu caráter genérico erga omnes.

Decerto é que essa atuação proativa dos nossos Tribunais tem levantado grandes discussões na doutrina e jurisprudência.

\subsection{Dos posicionamentos favoráveis ao ativismo judicial}

Em uma posição contrária, estão aqueles que advogam pela atuação proativa dos magistrados brasileiros.

O Poder Judiciário possui legitimidade para inovar a legislação brasileira, o principal fundamento estaria na Constituição Federal, que confere tal prerrogativa ao Supremo Tribunal Federal, principalmente se essa atuação for para defesa de direitos fundamentais.

$\mathrm{O}$ ativismo judicial é um instrumento a ser utilizado em prol da democracia brasileira. $\mathrm{O}$ artigo $5^{\circ}$, inciso XXXV da Constituição Federal consagra o princípio da inafastabilidade da jurisdição, logo, a atuação proativa do magistrado seria importante para ampliar e concretizar a aplicação do direito, trazendo justiça para o caso concreto.

É cediço que, para uma verdadeira aplicação dos direitos e garantias fundamentais previstos na Carta Magna, principalmente quando se trata de políticas públicas, torna-se de extrema necessidade a participação do Poder Judiciário.

No Judiciário brasileiro, é perceptível, principalmente, no Supremo Tribunal Federal, uma jurisprudência mais proativa.

A fim de ilustrar a tese, é possível citar vários casos de aplicação direta da Constituição a situações não contempladas em seu texto e sem prévia manifestação do Poder Legislativo ${ }^{14}$. A fidelidade partidária é um desses. O Supremo Tribunal Federal declarou que a vaga no Congresso é do partido político, aplicando como fundamentação o princípio democrático ${ }^{15}$. Outra situação é a vedação do nepotismo aos Poderes Legislativo e Judiciário, previsto na Súmula Vinculante $n^{\circ}$. 13, fundamentada, principalmente, nos princípios da impessoalidade e da moralidade ${ }^{16}$.

Aliás, as súmulas vinculantes editadas pelo Supremo Tribunal Federal, com previsão no artigo 103-A da Carta Magna, têm se mostrado um importante instrumento do ativismo judicial, uma vez que após reiteradas decisões sobre determinada matéria, o STF de ofício poderá editar as referidas súmulas que terão aplicação imediata em relação aos demais órgãos do Poder Judiciário e à administração pública direta e indireta, nas esferas federal, estadual e municipal.

13 ADEODATO, João Maurício. Uma Teoria Retórica da Norma Jurídica e do Direito Subjetivo. São Paulo: Noeses, 2011. p. 243.

14 A título exemplificativo podem ser citadas, dentre tantas, a ADI 4277 e ADPF 132, vinculadas ao reconhecimento da possibilidade de fixação de união estável entre pessoas do mesmo sexo (disponível em http://www.stf.jus.br/portal/cms/verNoticiaDetalhe. asp?idConteudo=178931), bem como, ADI 4983, afeta à inconstitucionalidade da Lei cearense n. ${ }^{\circ}$ 15.299/2013, que regulamentou a vaquejada como prática esportiva (disponível em http://www.stf.jus.br/portal/cms/verNoticiaDetalhe.asp?idConteudo=326838). 15 ADI 5081, de relatoria do Ministro Luís Roberto Barroso. Disponível em: < http://www.stf.jus.br/portal/cms/verNoticiaDetalhe.asp?idConteudo=292424>. Acesso em 16 dez. 2016.

16 BRASIL. Supremo Tribunal federal. Aplicação das Sumulas no STF. Disponível em: < http://www.stf.jus.br/portal/jurispruden$\mathrm{cia} /$ menusumario.asp?sumula=1227>. Acesso em: 16 dez. 2016. 
A polêmica é intensa, entretanto, pode ser intensificada quando se fala na categoria de ativismo judicial quando da imposição de condutas ou de abstenção ao Poder Pública, em matéria de políticas públicas.

Cotidianamente, o Poder Judiciário, em especial as Justiças Estadual e Federal de todo país, uma vez que o STF ainda não apreciou tal matéria em caráter definitivo, tem decidido condenando a União, Estado e Município a custear medicamentos e serviços médicos, até mesmo não previstos na lista e protocolo do Ministério da Saúde ou das Secretarias Estaduais e Municipais.

O Poder Judiciário, mediante provocação, intervém nas hipóteses em que há violação ao núcleo essencial dos direitos fundamentais aptos à manutenção da dignidade humana e aos direitos da liberdade irredutíveis, que compõem a Teoria do Mínimo Existencial, teoria tal, segundo NABAIS ${ }^{17}$, indispensável à "intangibilidade fiscal de um mínimo de meios ou recursos materiais indispensáveis à salvaguarda dessa dignidade".

Ressalta-se que, havendo a necessidade de ponderação de acordo com critérios de conveniência e oportunidade, uma fixação de prioridades do Estado, especialmente não se tratando de direitos ligados ao mínimo existencial, deve ser preservada a separação de poderes, reconhecendo a competência da Administração Pública na realização dos referidos juízos.

Aqui, deve-se trazer à baila que a intervenção do Poder Judiciário deve-se pautar no controle jurídico da razoabilidade do ato do poder público. Ou seja, é possível concretizar, por meio da intervenção judicial, o núcleo básico de direitos, por meio de coercitividade, mas com justa medida para alcançar os fins pretendidos.

É forçoso concluir a existência de uma nova conceituação para os direitos e deveres tratados na Constituição de 1988. Existe uma intensa demanda advinda da sociedade para tutela destes direitos. Assim, a legitimidade da atuação "protagonista" do Poder Judiciário decorre da própria vontade da Constituição.

Por fim, mas sem encerrar o debate, mostra-se essencial citar o posicionamento de Luis Roberto Barro$\mathrm{SO}^{18}$ :

[...] o ativismo judicial, até aqui, tem sido parte da solução, e não do problema. Mas ele é um antibiótico poderoso, cujo uso deve ser eventual e controlado. Em dose excessiva, há risco de se morrer da cura. A expansão do Judiciário não deve desviar a atenção da real disfunção que aflige a democracia brasileira: a crise de representatividade, legitimidade e funcionalidade do Poder Legislativo. Precisamos de reforma política. E essa não pode ser feita por juízes.

\subsection{Dos posicionamentos contrários ao ativismo judicial}

A primeira crítica à atitude ativista dos magistrados reside na análise de legitimidade. O Poder Judiciário não teria legitimidade democrática, para se levantar contra os atos dos Poderes instituídos pelo povo. Os membros da magistratura brasileira não foram eleitos por voto do povo, logo como poderia alterar ou criar legislação elaborada justamente por aqueles que foram eleitos pela vontade popular.

Entretanto, não é possível esquecer que alguns magistrados, para buscar justiça, passam a descuidar de seus deveres de fundamentar, razoavelmente, os seus julgados e proferem decisões sob as vestes do politicamente correto, mas travestido de uma retórica inflamada. Com essa prática, o magistrado pode fazer tudo o que quiser o que pode trazer danos irreversíveis a valores conquistados pelo Estado Democrático de Direito.

Esse decisionismo do magistrado pode ser danoso à democracia, uma vez que juízes não eleitos pela vontade popular, em regra, estão passando por cima de criações do legislador, o que influencia na separação dos poderes, princípio basilar esculpido na Carta Magna. Além disso, essa atuação atentaria, diretamente,

17 NABAIS, José Casalta. O Dever fundamental de pagar impostos. Coimbra: Almedina, 2004. p. 562.

18 BARROSO, Luís Roberto. Ativismo Judicial e Legitimidade Democrática. Disponível em: < http://www.oab.org.br/oabeditora/users/revista/1235066670174218181901.pdf>. Acesso em: 06 jun. 2014. 
contra o princípio da segurança jurídica, uma vez que o direito ficaria preso ao temperamento peculiar do magistrado.

Quando o Juiz, em uma atuação proativa, inova o ordenamento jurídico, estaria interferindo na função do Poder Legislativo.

Nesse contexto, Lenio Streck ${ }^{19}$ afirma:

Os juízes (e a doutrina também é culpada), que agora deveriam aplicar a Constituição e fazer filtragem das leis ruins, quer dizer, aquelas inconstitucionais, passaram a achar que sabiam mais do que o constituinte. Saímos, assim, de uma estagnação para um ativismo, entendido como a substituição do Direito por juízos subjetivos do julgador. Além disso, caímos em uma espécie de pan-principiologismo, isto é, quando não concordamos com a lei ou com a Constituição, construímos um princípio. [...] Tudo se judicializa. Na ponta final, ao invés de se mobilizar e buscar seus direitos por outras vias (organização, pressões políticas, etc.), o cidadão vai direto ao Judiciário, que se transforma em um grande guichê de reclamações da sociedade. Ora, democracia não é apenas direito de reclamar judicialmente alguma coisa. Por isso é que cresce a necessidade de se controlar a decisão dos juízes e tribunais, para evitar que estes substituam o legislador. E nisso se inclui o STF, que não é — e não deve ser — um super poder.

De igual modo, João Maurício Adeodato ${ }^{20}$ assevera que:

A doutrina tem procurado não apenas explicar essa evolução do direito positivo, mas também, em sua importante função pragmática, controlar o poder criador do juiz e evitar decisionismos. Isso não apenas nos casos de antinomias e lacunas, nos quais falha claramente a concepção silogística, mas também no dia a dia do direito.

É de bom alvitre acrescentar que a aplicação do ativismo traduz uma ineficiência administrativa na resolução da demanda, além, é claro, de representar uma crise de legitimidade democrática: cada vez mais demandas que antes poderiam se resolver no âmbito dos poderes Executivo e Legislativo, com legitimidade investida para tal, acaba exaurindo-se no âmbito do Judiciário.

Por fim, ressalta-se que o ativismo dos magistrados tende a gerar uma exclusividade do Poder Judiciário e um enfraquecimento dos demais poderes.

\section{DA PRINCIPIOLOGIA VINCULADA À CONCRETIZAÇÃO DO DIREITO FUNDAMENTAL À BOA GESTÃO PÚBLICA}

O reconhecimento do sistema jurídico como incompleto, dinâmico e aberto proporciona sua visualização por meio de valores, princípios e regras. Enquanto as últimas correspondem, geralmente, ao ideário da segurança jurídica, os princípios, por clara flexibilização, conforme lição de Fernando Rodrigues Martins ${ }^{21}$, atuam no campo da justiça, ao passo que os valores têm a especial magnitude de construção do sistema jurídico, especialmente, por meio da cultura e experiência.

Nesse contexto, segundo apresentado por Robert Alexy²2, há a necessidade de se buscar uma distinção teórico-normativa entre regras e princípios. Segundo o autor, regras são comandos definitivos, aplicadas por meio da subsunção, ao passo que os princípios, noutro vetor, são comandos de otimização, cabendo, nesse caso, em situações de colisão de princípios diversos, lançar mão da ponderação para que chegar a um equilíbrio.

19 STRECK, Lenio Luiz. Ativismo judicial não é bom para a democracia. Disponível em <http://www.conjur.com.br/2009-mar-15/ entrevista-lenio-streck-procurador-justica-rio-grande-sul>. Acesso em 06 jun. 2014.

20 ADEODATO, João Maurício. Uma Teoria Retórica da Norma Jurídica e do Direito Subjetivo. São Paulo: Noeses, 2011. p. 245.

21 MARTINS, Fernando Rodrigues. Controle do patrimônio público. 4. ed. São Paulo: RT. 2010. p. 223.

22 ALEXY, Robert. Princípios formais e outros aspectos da Teoria Discursiva do Direito. Rio de Janeiro: Forense. 2014. p. 05. 
Os princípios, vistos isoladamente, não representam o todo da Administração Pública, sendo certo que se faz necessária uma análise sistemática de todos esses fundamentos para se buscar uma interpretação adequada do que se entende por Poder Público.

Os princípios norteadores não existem "para” a Administração. Há, aqui, uma via de mão dupla: os princípios têm a função de fazer valer a necessária superioridade da Administração, em prol da busca incessante pelo bem como, além de, principalmente, servirem de proteção dos direitos fundamentais e da dignidade da pessoa humana.

Nesse sentido, os princípios apresentam-se como um guia ou um caminho para se buscar, sempre, o dever de máxima eficiência na prestação das atividades do Estado, conforme aponta Walber de Moura Agra ${ }^{23}$ :

A res publica expressa que as decisões políticas devem ser tomadas em benefício da população, e que os mandatários e os gestores públicos têm a obrigação de exercer suas funções de forma a considerar o bem público como algo sacro, densificando a eficiência dos órgãos estatais no atendimento das demandas coletivas.

Na lição de Luís Roberto Barroso ${ }^{24}$, a dignidade relaciona-se tanto com a liberdade e valores do espírito quanto as condições materiais de subsistência. O desrespeito a esse princípio terá sido um dos estigmas dos séculos que se encerrou e a luta por sua afirmação, um símbolo do novo tempo. Ele representa a superação da intolerância, da discriminação, de exclusão social, da violência, da incapacidade de aceitar o outro, o diferente, na plenitude de sua liberdade de ser, pensar e criar.

Ao versar sobre a principiologia voltada à materialização do direito fundamental à boa Administração Pública, resta impossível não enfrentar o postulado da moralidade, o qual representa termo de difícil conceituação, tanto no campo do direito quanto no da teoria política.

Maria Gorete Dal Bosco ${ }^{25}$ destaca que mencionado princípio representa o que a doutrina costuma chamar de termos genéricos, ou conceitos expressados por termos genéricos, que aparecem nos textos legais não acompanhados do significado que o legislador quis emprestar a tais palavras.

Ao pensar em moralidade, deve-se fazer uma opção por uma "moral da responsabilidade", como defende Maria Gorete Dal Bosco ${ }^{26}$, impondo-se aos cidadãos e, sobretudo, ao gestor público, a tarefa de levar a sério a construção da realidade social, diante da constatação de que o fortalecimento da democracia é um dever moral de todos quantos vivem em um país democrático.

Mais do que nunca, aplica-se a máxima de que governos morais são os que perseguem finalidades coincidentes com as aspirações dos governados, as quais, reiteradamente, cada vez mais se confundem com a honestidade no trato das questões públicas — o que quer dizer, claramente, inexistência de corrupção. Tais aspirações voltam-se, também, à busca da otimização de recursos e estruturas públicas, o que repercute na qualidade e eficiência administrativa.

Gustavo Binenbojm ${ }^{27}$ destaca que os princípios jurídicos encerram mandados de otimização, no sentido de comandos normativos que apontam para uma finalidade ou estado de coisas a ser alcançado, mas que admitem concretização em graus de acordo com as circunstâncias fáticas e jurídicas.

De igual modo, destaca-se, mais uma vez, a contribuição de Robert Alexy ${ }^{28}$ quanto à necessidade de visualização dos princípios como elementos de concretização social das normas expedidas, de modo a se

23 AGRA, Walber de Moura. Republicanismo. Porto Alegre: Livraria do Advogado, 2005. p. 61.

24 BARROSO, Luís Roberto. Curso de direito constitucional contemporâneo: os conceitos fundamentais e a construção do novo. São Paulo: Saraiva. 2009. p. 252.

25 DAL BOSCO, Maria Gorete. Discricionariedade em políticas públicas. Curitiba: Juruá. 2009. p. 99.

26 Idem, p. 100.

27 BINENBOJM, Gustavo. Uma teoria do direito administrativo: Direitos fundamentais, democracia e constitucionalização. Rio de Janeiro: Renovar. 2008. p. 30.

28 ALEXY, Robert. Princípios formais e outros aspectos da Teoria Discursiva do Direito. Rio de Janeiro: Forense. 2014. p. 13-14. 
buscar uma conformidade entre o ordenamento (de caráter objetivo) e sua eficácia social. Em suma, os princípios apresentam-se como mecanismos de superação entre o hiato que separa a norma jurídica de sua real efetividade.

Um governo que preza pela moralidade e respeito aos demais fundamentos norteadores da Administração Pública, zelando pelos direitos fundamentais do cidadão, tem a seu favor a garantia de não sofrer qualquer tentativa de intervenção por parte do Poder Judiciário.

Ainda no campo da principiologia voltada ao controle dos atos administrativos, de grande relevância destacar a abordagem sistemática tecida por Juarez Freitas ${ }^{29}$, o qual cita diversos princípios fundamentais que regem as relações de administração no Brasil, a saber:

(1) princípio do interesse público e correlata subordinação das ações estatais ao princípio da dignidade humana; (2) princípio da proporcionalidade ou da simultânea vedação de excessos e omissões causadoras de danos juridicamente injustos; (3) princípio da legalidade temperada ou nuançada; (4) princípio da imparcialidade (ou da impessoalidade), derivado do princípio geral da igualdade, que veda discriminações negativas e determina discriminações inversas ou positivas; (5) princípio da moralidade pública e o subprincípio da probidade administrativa; (6) princípio da publicidade ou da máxima transparência; (7) princípio da confiança legítima ou da boa-fé recíproca; (8) princípio da motivação; (9) princípio da ampla sindicabilidade e o princípio da participação; (10) princípio da unicidade da jurisdição e consequente não-cerceamento do acesso ao Poder Judiciário em casos de lesão ou ameaça de lesão a diretos do cidadão ou da Administração Pública; (11) princípios da eficiência, da eficácia e da economicidade; (12) princípio da legitimidade; (13) princípio da responsabilidade objetiva da Administração Pública; (14) princípio da precaução e da prevenção, válidos não apenas na esfera ambiental; (15) princípio da intervenção essencial que determina o dever de o Estado promover, de imediato, a tutela do núcleo dos direitos fundamentais, assim como de adotar atuação preferencialmente subsidiária e incentivadora da emancipação crescente da cidadania.

Em pleno século XXI, não mais se pode admitir que o trato da coisa pública seja assunto de desinteresse da coletividade. Cada cidadão, individualmente ou reunido em grupos, mediante provocação do Poder Judiciário, deve exigir integridade na gestão pública, com a consequente materialização dos direitos fundamentais, os quais, "vinculam os órgãos administrativos em todas as suas formas e atividades ${ }^{30 "}$.

A preocupação com o direito fundamental à boa gestão pública não é tema vinculado apenas ao direito brasileiro. Destaca-se que a Carta dos Direitos Fundamentais da União Europeia (Carta de Nice) ${ }^{31}$, proclamada em dezembro de 2000, em seu artigo 41, expressamente, trouxe a menção ao direito fundamental a uma boa administração pública, como se vê:

\section{ARTIGO 41. ${ }^{\circ}$}

Direito a uma boa administração

1. Todas as pessoas têm direito a que os seus assuntos sejam tratados pelas instituições, órgãos e organismos da União de forma imparcial, equitativa e num prazo razoável.

2. Este direito compreende, nomeadamente:

a) $\mathrm{O}$ direito de qualquer pessoa a ser ouvida antes de a seu respeito ser tomada qualquer medida individual que a afete desfavoravelmente;

b) $\mathrm{O}$ direito de qualquer pessoa a ter acesso aos processos que se lhe refiram, no respeito pelos legítimos interesses da confidencialidade e do segredo profissional e comercial;

c) A obrigação, por parte da administração, de fundamentar as suas decisões.

3. Todas as pessoas têm direito à reparação, por parte da União, dos danos causados pelas suas instituições ou pelos seus agentes no exercício das respetivas funções, de acordo com os princípios gerais comuns

29 FREITAS, Juarez. O controle dos atos administrativos e os princípios fundamentais. 4. ed. São Paulo: Malheiros. 2009. p. 53.

30 SARLET, Ingo Wolfgang. A eficácia dos direitos fundamentais. 5. ed. Porto Alegre: Livraria dos Advogados. 2005. p. 365.

31 CARTA dos direitos fundamentais da União Europeia Disponível em: < http://www.europarl.europa.eu/charter/pdf/text_ pt.pdf $>$. Acesso em: 24 set. 2016. 
às legislações dos Estados-Membros.

4. Todas as pessoas têm a possibilidade de se dirigir às instituições da União numa das línguas dos Tratados, devendo obter uma resposta na mesma língua.

Ao analisar o direito fundamental a uma boa administração pública previsto na Carta de Direitos Fundamentais da União Europeia, Jónatas Machado ${ }^{32}$ aponta:

Pretende-se criar uma administração bem dirigida, com capacidade de prestação, funcionalmente ordenada e adequada, estruturada com base nos direitos fundamentais e nos princípios estruturantes do direito da União Europeia, como a democracia e o Estado de direito.

A Constituição de 1988, muito antes da Carta dos Direitos Fundamentais da União Europeia, consagrou um direito fundamental à boa administração, de modo que esse está, principalmente (não exclusivamente), ancorado: no artigo $1^{\circ}$, III, que consagra a dignidade da pessoa humana como fundamento da República e no artigo 37, em que estão elencados os princípios diretivos da administração pública. A nossa Constituição, como se percebe, segundo destacado por Ingo Sarlet ${ }^{33}$, foi mais adiante. Além de, implicitamente, consagrar o direito fundamental à boa administração, ela já previu, expressamente, os critérios, diretrizes, princípios que norteiam e permitem a concretização dessa ideia de boa administração.

Em que pese a inexistência de previsão expressa no texto constitucional acerca do direito fundamental a uma boa administração pública, inegável que a redação trazida pelo artigo $5^{\circ}, \mathbb{\Omega} 2^{\circ}$, da Constituição Federal, o contemplou no chamado "rol aberto dos direitos fundamentais", ao afirmar que "os direitos e garantias expressos nesta Constituição não excluem outros decorrentes do regime e dos princípios por ela adotados, ou dos tratados internacionais em que a República Federativa do Brasil seja parte".

Seria uma tarefa exaustiva (talvez, impossível) ao legislador tentar delinear no corpo do texto constitucional, de forma peremptória, todos os direitos fundamentais que devam ser atribuídos ao homem. Nesse sentido, como forma de salvaguardar eventuais direitos não expressamente elencados, houve a motivada e coerente opção de se inserir no referido artigo $5^{\circ}$, $\int 2^{\circ}$, da Constituição Federal, uma espécie de soldado de reserva, com a função de assegurar a garantia desses direitos fundamentais não categoricamente positivados.

Em que pese a ausência de vinculação expressa no texto constitucional do direito fundamental à boa administração, assina Vanice Regina do Valle ${ }^{34}$ restar inequívoco que seu reconhecimento tem o condão de propiciar a materialização de um considerável feixe de direitos fundamentais previstos na Constituição Federal, com especial atenção para aqueles de caráter prestacional.

Não há, pois, a possibilidade de se buscar uma gradação entre direitos fundamentais, a partir da existência (ou não) de sua positivação no texto constitucional, uma vez que tanto os princípios implícitos quanto os explícitos, constituem-se, segundo Carlos Ari Sundfeld ${ }^{35}$, como verdadeiras normas jurídicas.

Em razão, pois, em relação ao que se propõe no presente artigo, torna-se conveniente efetuar a análise de alguns dos mencionados princípios listados, dentre outros, por Juarez Freitas.

\subsection{Princípio do interesse público e correlata subordinação das ações estatais ao princípio da dignidade humana}

$\mathrm{Na}$ dicção de Juarez Freitas ${ }^{36}$, o princípio do interesse público prescreve que, em caso de colisão, deve preponderar a vontade geral legítima (o "bem de todos", no dizer do artigo $3^{\circ}$, da CF) sobre a vontade,

32 MACHADO, Jónatas E. M. Direito da União Europeia. Coimbra: Coimbra, 2010. p. 254.

33 SARLET, Ingo Wolfgang. A Administração Pública e os direitos fundamentais. 2006. Disponível em: < http://www.trf4.jus.br/ trf4/upload/arquivos/emagis_atividades/ingowolfgangsarlet.pdf>. Acesso em: 23 set. 2016.

34 VALLE, Vanice Regina do. Direito fundamental à boa administração e governanç. Belo Horizonte: Fórum, 2011. p. 161.

35 SUNDFELD, Carlos Ari. Fundamento de direito público. 4. ed. São Paulo: Malheiros, 2000. p. 150.

36 FREITAS, Juarez. O controle dos atos administrativos e os princípios fundamentais. 4. ed. São Paulo: Malheiros. 2009. p. 54. 
egoisticamente, articulada ou facciosa, sem que aquela volição se confunda com a simples vontade do aparato estatal, tampouco com o desejo da maioria.

Celso Antônio Bandeira de Mello ${ }^{37}$ tem uma clássica definição sobre mencionado princípio, e descreve-o como "verdadeiro axioma reconhecível no moderno Direito Público. Proclama a superioridade do interesse da coletividade, firmando a prevalência dele sobre o particular, como condição até mesmo, da sobrevivência e asseguramento desse último. É pressuposto de uma ordem social estável, em que todos e cada um possam sentir-se garantidos e resguardados".

Na mesma toada, José dos Santos Carvalho Filho ${ }^{38}$ defende que o interesse público acaba sendo ponto de referência para o controle da legalidade quando a Administração se desvia do objetivo a que se dirige o ato. O controle da finalidade das condutas administrativas representa o próprio controle do interesse público.

Vê-se, pois, que o controle operacionalizado por meio da utilização do princípio da supremacia do interesse público tem o condão de garantir, em razão do caráter, naturalmente, egocêntrico do ser humano ${ }^{39}$, a ponderação dos direitos fundamentais lingados à preservação da dignidade da pessoa humana.

Nesse sentido, continua Juarez Freitas ${ }^{40}$ a defender que o interesse público guarda correlação íntima com a tutela da dignidade de todas as pessoas e de cada uma. O cidadão não é sujeito passivo da Administração, mas, sim, um “cidadão maior". É para o desenvolvimento humano que se ergue o Estado-Administração.

Nesse sentido, cabe ao Estado, por meio do Poder Judiciário, arvorar-se contra o próprio Estado, de modo que sejam ofertadas a todo cidadão, independentemente de sua classe social, amplo e irrestrito acesso às prestações públicas garantidoras da dignidade humana, podendo citar, nesse contexto, a intervenção da magistratura em decisões de fornecimento de medicamentos, determinação de internações hospitalares e realização de procedimentos médico-cirúrgicos, disponibilização de vagas em creches e escolas, dentre outros.

Destaca-se, ainda, que o agir do Poder Judiciário voltado à manutenção da subordinação do Estado aos preceitos constitucionais não está vinculado, apenas, à oferta prestações públicas de caráter individual, como anteriormente demonstrado. Cita-se, assim, também, a necessidade de intervenção do Judiciário sempre que houver risco à manutenção dos demais princípios que regem a função estatal, a exemplo do julgamento do Supremo Tribunal Federal acerca da vedação da prática de nepotismo, conduta em clara afronta às regras da impessoalidade e moralidade administrativa, com assento constitucional.

E é esse "desenvolvimento" que justifica a primazia legítima e democrática do interesse público sobre os anseios particulares, sempre, com vistas à preservação dos direitos fundamentais estampados na Carta Constitucional.

\subsection{Princípio da proporcionalidade ou da simultânea vedação de excessos e omissões causadoras de danos juridicamente injustos}

Segundo o magistério de Juarez Freitas ${ }^{41}$, o princípio da proporcionalidade determina (não apenas exorta) que a Administração Pública "lato sensu" evite agir com demasia ou de modo insuficiente, inoperante ou omissivo na consecução de seus objetivos.

Ocorre violação ao princípio da proporcionalidade quando a Administração encontra-se diante de dois valores legítimos e confere prioridade a um, em detrimento ao sacrifício exagerado de outro.

37 MELLO, Celso Antônio Bandeira de. Curso de Direito Administrativo. São Paulo: Malheiros. 2003. p. 60.

38 CARVALHO FILHO, José dos Santos. Supremacia do interesse público. São Paulo: Atlas, 2010. p. 74-75.

39 CARVAlHO FILHO, José dos Santos. Supremacia do interesse público. São Paulo: Atlas, 2010. p. 75.

40 FREITAS, Juarez. O controle dos atos administrativos e os princípios fundamentais. 4. ed. São Paulo: Malheiros. 2009. p. 54.

41 FREITAS, Juarez. O controle dos atos administrativos e os princípios fundamentais. 4. ed. São Paulo: Malheiros. 2009. p. 61. 
Essa disparidade na escolha de um direito em preterição a outro foi muito bem demonstrada por Lenio Streck $^{42}$ na ocasião em que o Poder Judiciário da comarca de Joinville (SC) determinou que a municipalidade, em sede de Ação civil pública promovida pelo Ministério Público, criasse 2.948 vagas de ensino fundamental juntamente à rede pública local, eis que o gestor optou por conceder subvenção social à equipe de futebol local $(\mathrm{R} \$ 1.750 .000,00)$.

O administrador público está vinculado ao sacrifício do mínimo, em favor da preservação do máximo de direitos. Isso significa que o princípio da proporcionalidade, nas suas duas facetas (vedação de excesso e vedação de inoperância/omissão), apresenta-se, especialmente, relevante ao impor moderação no exercício de poderes e ao cobrar, diligentemente, o cumprimento dos deveres prestacionais positivos, de sorte a ser incorporado, obrigatoriamente, entre os parâmetros de avaliação sistêmica dos resultados da gestão pública, na busca pelo aperfeiçoamento aos preceitos fundamentais.

Reiteradamente, os Tribunais Superiores têm proferido decisões que abarcam o princípio da proporcionalidade, em atenção, também, aos direitos fundamentais trazidos na Constituição Federal ${ }^{43}$.

\subsection{Princípio da intervenção estatal promotora do núcleo essencial dos direitos fundamentais}

A análise desse princípio nos revela a necessidade de um Estado atinente ao direito fundamental à boa administração pública e, assim, promotor do "bem de todos", segundo Juarez Freitas ${ }^{44}$.

Dessa lógica segue a irrenunciável titularidade da prestação eficiente e eficaz dos serviços de natureza pública (mesmo que, por vezes, delegável a terceiros).

Acolhido o dever de promoção do núcleo essencial dos direitos fundamentais, especialmente do direito fundamental à boa administração pública, aperfeiçoa-se lídima mudança paradigmática no controle dos atos administrativos. Tal mudança revela-se desafiadora de antigos conformismos, sobretudo, diante de exemplos reiterados em que o Estado falha na tutela do chamado "mínimo existencial", deixando à deriva tais preceitos basilares trazidos na Carta de 1988.

Tem-se que a tarefa mais produtiva do controle sistemática das relações administrativas consiste em bem hierarquizar as escolhas administrativas, com eficiência, economicidade, eficácia, prevenção e precaução, de maneira a solucionar tensões e lacunas sociais.

Segundo Juarez Freitas ${ }^{45}$, faz-se imprescindível no cumprimento do controle sistemático dos atos administrativos "lato sensu", adotar novo estilo, segundo o qual os princípios e direitos fundamentais são fortemente vinculantes, muito além daquela visão de que seriam meros recursos vagos ou de falso alívio proporcionado pela retórica ornamental.

Urge realizar um controle assertivo e capaz de oferecer vitalidade à combinação e à complementação dos princípios norteadores do Estado Democrático de Direito, com a finalidade de se conferir à sociedade, em especial, àquela camada mais vulnerável, uma vida digna, condizente com os direitos fundamentais espraiados na Constituição Federal de 1988.

42 STRECK, Lenio. Verdade e Consenso. Constituição, hermenêutica e teorias discursivas. São Paulo: Saraiva. 2011. p. 178.

43 STJ: REsp 1.335.153-RJ, Rel. Min. Luis Felipe Salomão, julgado em 28/5/2013 e REsp 1.334.097-RJ, Rel. Min. Luis Felipe Salomão, julgado em 28/5/2013, veiculados no Informativo n. 527 (direito ao esquecimento).

44 FREITAS, Juarez. O controle dos atos administrativos e os princípios fundamentais. 4. ed. São Paulo: Malheiros. 2009. p. 144.

45 FREITAS, Juarez. O controle dos atos administrativos e os princípios fundamentais. 4. ed. São Paulo: Malheiros. 2009. p. 151. 


\section{Considerações Finais}

Não se pode interpretar cláusula de proteção à sociedade em desfavor desta. É desarrazoado sustentar-se que o dito ativismo judicial fira a Democracia Participativa, quando esta sofre violações muito mais graves diante de não atendimento de dever prestacional.

Esse dever prestacional é materializado por meio da execução de políticas públicas que atuam como verdadeiros instrumentos valiosos para a concretização dos planos de governo a serem implementados, sempre eleitos para a busca incessante do bem comum.

Por vezes, por razões que extrapolam a natureza do presente artigo, essas políticas públicas são negadas ao cidadão, em razão de escolhas obtusas dos administradores.

Enquanto poder contramajoritário, cabe ao Judiciário a defesa da Democracia ainda quando isto significar a intervenção judicial na Administração Pública que insista em desrespeitar e se colocar acima dos ditames constitucionais e legais que vinculam a todos nós.

Não se pretende sustentar que o Poder Judiciário pode imiscuir-se na função do Poder Executivo de modo a privilegiar uma política pública em detrimento de outra. O que se apregoa, em sintonia com o que se espera de um Estado de Direito, é a possibilidade de judicialização em casos de omissão relevante, que submeta a risco o núcleo essencial dos direitos fundamentais.

Defender a taxatividade do princípio da separação dos poderes como forma de mitigar a judicialização de políticas públicas representa um verdadeiro contrassenso, uma afronta ao Estado Democrático de Direito, que deve primar pela valoração e respeito aos direitos do homem, dentre os quais aquele relacionado a uma gestão administrativa proba e competente.

É inadmissível a argumentação rotineira de carência de recursos (reserva do possível) se vemos, a cada dia, o desperdício de verbas públicas com publicidade, eventos voltados, unicamente, à promoção pessoal dos agentes públicos, bem como à execução de obras faraônicas desnecessárias.

Cabe, sim, ao Poder Judiciário agir como o fiel da balança de modo a equacionar, quando necessário, a correta materialização de políticas públicas atinentes à manutenção do núcleo essencial dos direitos fundamentais, quando em xeque o mínimo existencial que deve ser conferido a todo ser humano.

\section{REFERÊNCIAS BIBLIOGRÁFICAS}

ADEODATO, João Maurício. Uma Teoria Retórica da Norma Jurídica e do Direito Subjetivo. São Paulo: Noeses, 2011.

AGRA, Walber de Moura. Republicanismo. Porto Alegre: Livraria do Advogado, 2005.

AGUIAR, Claudio Tenório Figueiredo. Ministério Público e políticas públicas. Coordenadora: Patrícia Villela. Rio de Janeiro: Lumen Juris, 2009.

ALEXY, Robert. Princípios formais e outros aspectos da Teoria Discursiva do Direito. Rio de Janeiro: Forense, 2014.

BARROSO, Luís Roberto. Ativismo Judicial e Legitimidade Democrática. Disponível em: <http://www.oab.org. br/oabeditora/users/revista/1235066670174218181901.pdf>. Acesso em: 06 jun. 2014.

BARROSO, Luís Roberto. Curso de direito constitucional contemporâneo: os conceitos fundamentais e a construção do novo. São Paulo: Saraiva, 2009.

BARroSO, Luís Roberto. Fundamentos Teóricos e Filosóficos do Novo Direito Constitucional Brasileiro 
(Pós-modernidade, Teoria Crítica e Pós-Positivismo). In: BARROSO, Luís Roberto. (Org.). A Nova Interpretação Constitucional: Ponderação, Direitos Fundamentais e Relações Privadas. 2. ed. Rio de Janeiro: Renovar, 2006.

BINENBOJM, Gustavo. Uma teoria do direito administrativo: Direitos fundamentais, democracia e constitucionalização. Rio de Janeiro: Renovar, 2008.

CARVALHO FILHO, José dos Santos. Supremacia do interesse público. São Paulo: Atlas, 2010.

DAL BOSCO, Maria Gorete. Discricionariedade em políticas públicas. Curitiba: Juruá, 2009.

FREITAS, Juarez. O controle dos atos administrativos e os princípios fundamentais. 4. ed. São Paulo: Malheiros, 2009.

GOMES, Luiz Flávio. O STF está assumindo um ativismo judicial sem precedentes? Jus Navigandi, Teresina, ano 13, n. 2164, 4 jun. 2009. Disponível em: <http://http://jus.com.br/revista/texto/12921. Acesso em: 06 jun. 2014.

MACHADO, Jónatas E. M. Direito da União Europeia. Coimbra: Coimbra, 2010.

MARTINS, Fernando Rodrigues. Controle do patrimônio público. 4. ed. São Paulo: RT, 2010.

MELLO, Celso Antônio Bandeira de. Discricionariedade e Controle Judicial. 2. ed. São Paulo: Malheiros, 2010.

NABAIS, José Casalta. O Dever fundamental de pagar impostos. Coimbra: Almedina, 2004.

PAULO JUNIOR, José Marinho. Ministério Público e políticas públicas. Coordenadora: Patrícia Villela. Rio de Janeiro: Lumen Juris, 2009.

SARLET, Ingo Wolfgang. A Administração Pública e os direitos fundamentais. 2006. Disponível em: <http://www.trf4.jus.br/trf4/upload/arquivos/emagis_atividades/ingowolfgangsarlet.pdf>. Acesso em: 23 set. 2016.

SARLET, Ingo Wolfgang. A eficácia dos direitos fundamentais. 5. ed. Porto Alegre: Livraria dos Advogados. 2005.

SARMENTO, Daniel. A Constitucionalização do Direito: Fundamentos Teóricos e Aplicações Específicas. Rio de Janeiro. Lumen Juris, 2007.

STRECK, Lenio Luiz. Hermenêtica jurídica em crise: uma exploração hermenêutica da construção do direito. 10. ed. Porto Alegre: Livraria do Advogado, 2011.

STRECK, Lenio Luiz. Verdade e Consenso. Constituição, hermenêutica e teorias discursivas. São Paulo: Saraiva, 2011.

SUNDFELD, Carlos Ari. Fundamento de direito público. 4. ed. São Paulo: Malheiros, 2000.

VALLE, Vanice Regina do. Direito fundamental à boa administraşão e governança. Belo Horizonte: Fórum, 2011. 
Para publicar na revista Brasileira de Políticas Públicas, acesse o endereço eletrônico www.rbpp.uniceub.br

Observe as normas de publicação, para facilitar e agilizar o trabalho de edição. 